\title{
NOTES
}

\section{Effects of Polyelectrolytes on the Complexation between Pyrenesulfonate and Anthraquinonesulfonate Ions}

\author{
Yoshiya Kawabata, Tomoyuki Itaya, ${ }^{\dagger}$ Yuki Sasaki, Hiroshi OchiaI ${ }^{\dagger \dagger}$ \\ Kazuyoshi UEDA, and Akira IMAMURA \\ Department of Chemistry, Faculty of Science, Hiroshima University, \\ Kagamiyama, Higashi-Hiroshima 724, Japan
}

(Received October 3, 1994)

\begin{abstract}
KEY WORDS Polyelectrolyte / Counterion Binding / Charge-Transfer Complexation / Pyrenesulfonate / Anthraquinonesulfonate / Charge Density /
\end{abstract}

One of the most characteristic properties of aqueous polyelectrolyte solutions is the counterion binding by the polyion, ${ }^{1}$ due to electrostatic interactions between the polyion having many charged groups on the chain and counterions. As a result of this electrostatic interaction, polyelectrolyte solutions show various phenomena different from non-electrolyte polymer solutions. Therefore, many studies on the interactions between polyion and counterions have been reported. ${ }^{2-8}$ By adding simple electrolytes to a polyelectrolyte solution as added salts, charges on the polyion are screened out due to the counterion binding. Since counterions are bound to the polyion through the counterion binding, interaction between counterions themselves should occur in the vicinity of the polyion in addition to the interactions between the polyion and counterions. For example, when a hydrophobic salt, which has both ionic and non polar sites, is used as an added electrolyte, the hydrophobic and/or van der Waals interaction between them bound to the polyion may occur. In previous papers, ${ }^{9-11)}$ we reported association behavior of aromatic counterions, i.e., p-ethyl- benzenesulfonate $\left(\mathrm{EBS}^{-}\right), \quad p$-propylbenzenesulfonate $\left(\mathrm{PBS}^{-}\right)$, 2-naphthalenesulfonate (2$\mathrm{NpS}^{-}$) ions, in aqueous poly(allylammonium) chloride $\left(\mathrm{PAAH}^{+} \mathrm{Cl}^{-}\right)$solution. In these studies, it was found that $\mathrm{EBS}^{-}, \mathrm{PBS}^{-}$, and $2-\mathrm{NpS}^{-}$bound to the polyion through the counterion binding associate with each other in the vicinity of the polyion through hydrophobic and stacking interactions. The hydrophobic and stacking interactions are characteristic intermolecular interactions, and furthermore, charge-transfer (CT) interaction between electron-donative (donor) and electron-acceptive (acceptor) molecules is also important in vivo, i.e., an enzyme-coenzyme interaction. However, reports on CT interaction in aqueous media are relatively rare. Using the counterion binding and the concentration effects of polyelectrolytes, we can study CT interaction between donor and acceptor molecules in aqueous solutions as a reaction model in vivo. We studied CT interaction between aromatic counterions in the vicinity of polyions ${ }^{12-14}$; CT interactions between 9,10-dimethoxyanthracene-2-sulfonate $\left(\mathrm{DMACS}^{-}\right)$and 9,10-anthraquinone-2-

${ }^{\dagger}$ Present Address: Department of Applied Chemistry, Faculty of Engineering, Ehime University, Matsuyama 790, Japan.

${ }^{\dagger \dagger}$ To whom correspondence should be addressed. 
sulfonate (2-AQS $\left.{ }^{-}\right)$, and between 1-pyrenesulfonate $\left(\mathrm{PyS}^{-}\right)$and $2-\mathrm{AQS}^{-}$bound to polyions through the counterion binding. In general, the electrostatic interaction between polyion and counterions is considerably influenced by the charged groups, ${ }^{15,16}$ charge density of the polyion and its chain conformation. In the present work, we investigated the effects of polyelectrolytes (the charge density, variety of charged groups of the polyion, its flexibility) on CT complexation between $\mathrm{PyS}^{-}$ and $2-\mathrm{AQS}^{-}$in aqueous polyelectrolyte solutions by absorption spectroscopy and solubility measurement. From this study, the factors which control CT complex formation were clarified.

\section{EXPERIMENTAL}

\section{Materials}

Samples used in this study were poly(vinylammonium) chloride $\left(\mathrm{PVAH}^{+} \mathrm{Cl}^{-}\right)$, poly(allylammonium) chloride $\left(\mathrm{PAAH}^{+} \mathrm{Cl}^{-}\right)$, and poly(1,1-dimethyl-3,5-dimethylenepiperidinium) chloride $\left(\mathrm{PDDP}^{+} \mathrm{Cl}^{-}\right)$obtained from Mitsubishi Kasei Co., Ltd., and Nitto Boseki Co., Ltd., and Aldrich Chemical Co., Inc., respectively. The polymers were purified by reprecipitation as follows. $5 \%$ aqueous solution of $\mathrm{PVAH}^{+} \mathrm{Cl}^{-}$was precipitated with methanol contained $1.2 \mathrm{M} \mathrm{HCl}$ and dried in vacuo at room temperature for one week. $\mathrm{PAAH}^{+} \mathrm{Cl}^{-}$and $\mathrm{PDDP}^{+} \mathrm{Cl}^{-}$were purified by methods previously described. ${ }^{13,17}$ Weightaverage molecular weights of all the polymers were about $1 \times 10^{5}$. Chemical structures of $\mathrm{PVAH}^{+} \mathrm{Cl}^{-}, \mathrm{PAAH}^{+} \mathrm{Cl}^{-}, \mathrm{PDDP}^{+} \mathrm{Cl}^{-}$are shown in Chart 1. Sodium 1-pyrenesulfonate $\left(\mathrm{Na}^{+} \mathrm{PyS}^{-}\right)$and sodium 9,10-anthraquinone2-sulfonate $\left(\mathrm{Na}^{+} 2-\mathrm{AQS}^{-}\right)$of analytical grade were purchased from Molecular Probes Inc. and Tokyo Kasei Co., Ltd., respectively, and used without further purification. Deionized and distilled water was used as solvent. Concentration was expressed as residue molar concentration $(M)$ for polymers and molar con-

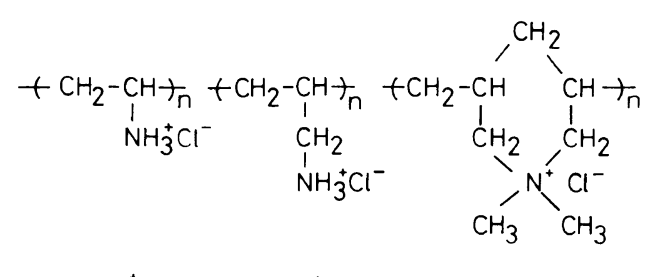

$\mathrm{PVAH}^{+} \mathrm{Cl}^{-} \quad \mathrm{PAAH}^{+} \mathrm{Cl}^{-} \quad \mathrm{PDDP}^{+} \mathrm{Cl}^{-}$

Chart 1. Chemical structures of $\mathrm{PVAH}^{+} \mathrm{Cl}^{-}, \mathrm{PAAH}^{+}$ $\mathrm{Cl}^{-}$, and $\mathrm{PDDP}^{+} \mathrm{Cl}^{-}$

centration $(M)$ for salts $\left(1 \mathrm{M}=1 \mathrm{~mol} \mathrm{dm}^{-3}\right)$.

\section{Measurements}

Absorption spectra were recorded at $25^{\circ} \mathrm{C}$ on a Shimadzu $265 \mathrm{FW}$ spectrophotometer equipped with a thermostated cell compartment. Quartz cells with a light path length of $2 \mathrm{~mm}$ and $10 \mathrm{~mm}$ were used.

Solubility measurements were made as follows. $\mathrm{Na}^{+} \mathrm{PyS}^{-}$and $\mathrm{Na}^{+} 2-\mathrm{AQS}^{-}$concentrates were added to polymer concentrates in small vials, to which an appropriate amount of water had been added, and followed by shaking and then standing for 1 day. Precipitation of the polymers and turbidity of solutions were judged visually. The tests were carried out at room temperature.

\section{RESULTS AND DISCUSSION}

Since either $\mathrm{PyS}^{-}$or $2-\mathrm{AQS}^{-}$associates themselves in the vicinity of $\mathrm{PVAH}^{+}$and PDDP $^{+}$, similarly to in the vicinity of $\mathrm{PAAH}^{+}$ as described previously, ${ }^{14}$ their association behavior is not discussed in this paper. First, we discuss the CT complexation between $\mathrm{PyS}^{-}$ and 2-AQS ${ }^{-}$in the presence of polyions. In all polymer systems, solutions of $\mathrm{Na}^{+} \mathrm{PyS}^{-} /$polymer and $\mathrm{Na}^{+} 2-\mathrm{AQS}^{-} /$polymer were colorless, whereas addition of the polymers to solutions containing both $\mathrm{Na}^{+} \mathrm{PyS}^{-}$and $\mathrm{Na}^{+} 2-\mathrm{AQS}^{-}$ caused color change to yellow, attributed to CT complexation between $\mathrm{PyS}^{-}$and 2-AQS ${ }^{-}$. Since color change of the solutions was not observed without the polymers even at the same 


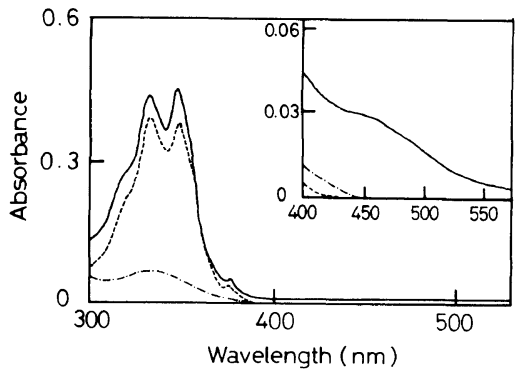

Figure 1. Absorption spectra of $\mathrm{Na}^{+} \mathrm{PyS}^{-} / \mathrm{PDDP}^{+} \mathrm{Cl}^{-}$ $(-), \mathrm{Na}^{+} 2-\mathrm{AQS}^{-} / \mathrm{PDDP}^{+} \mathrm{Cl}^{-}(----)$, and $\mathrm{Na}^{+} \mathrm{PyS}^{-} /$ $\mathrm{Na}^{+} 2-\mathrm{AQS}^{-} / \mathrm{PDDP}^{+} \mathrm{Cl}^{-}(-\cdot-)$ systems. Cells with a light path of $2 \mathrm{~mm}$ and $10 \mathrm{~mm}$ (for the CT band) were used. $\left[\mathrm{Na}^{+} \mathrm{PyS}^{-}\right]=1.10 \times 10^{-4} \mathrm{M},\left[\mathrm{Na}^{+} 2-\mathrm{AQS}^{-}\right]=$ $1.10 \times 10^{-4} \mathrm{M},\left[\mathrm{PDDP}^{+} \mathrm{Cl}^{-}\right]=4.40 \times 10^{-4} \mathrm{M}$.

salt concentration $\left(\left[\mathrm{Na}^{+} \mathrm{PyS}^{-}\right]=\left[\mathrm{Na}^{+} 2-\right.\right.$ $\left.\left.\mathrm{AQS}^{-}\right]=1.10 \times 10^{-4} \mathrm{M}\right)$, we concluded that CT complexation occurs between $\mathrm{PyS}^{-}$and 2-AQS ${ }^{-}$bound to the polyions through the counterion binding. Figure 1 shows the $a b-$ sorption spectra of the $\mathrm{Na}^{+} \mathrm{PyS}^{-} / \mathrm{PDDP}^{+}$ $\mathrm{Cl}^{-}, \quad \mathrm{Na}^{+} 2-\mathrm{AQS}^{-} / \mathrm{PDDP}^{+} \mathrm{Cl}^{-}, \mathrm{Na}^{+} \mathrm{PyS}^{-} /$ $\mathrm{Na}^{+} 2-\mathrm{AQS}^{-} / \mathrm{PDDP}^{+} \mathrm{Cl}^{-}$systems. In the $\mathrm{Na}^{+} \mathrm{PyS}^{-} / \mathrm{Na}^{+} 2-\mathrm{AQS}^{-} / \mathrm{PDDP}^{+} \mathrm{Cl}^{-}$system, a new broad absorption band with a maximum near $450 \mathrm{~nm}$ appeared, attributed to CT complexation between $\mathrm{PyS}^{-}$and 2-AQS ${ }^{-}$. In both $\mathrm{PVAH}^{+} \mathrm{Cl}^{-}$and $\mathrm{PAAH}^{+} \mathrm{Cl}^{-}$systems, similar spectroscopic changes were observed (not shown here).

Figure 2 shows a comparison of the CT band intensity of these three systems under the same conditions. The CT band at nearly the same peak position means that the same CT complex is formed in all three systems. But, the intensity of the $\mathrm{CT}$ band increases in the following order: $\mathrm{PDDP}^{+} \mathrm{Cl}^{-}$system $<\mathrm{PVAH}^{+} \mathrm{Cl}^{-}$system $<$ PAAH ${ }^{+} \mathrm{Cl}^{-}$system.

To determine the stoichiometries of the CT complexes in three polymer systems, the continuous variation method (Job plot ${ }^{18}$ ) was used for the CT band (absorbance at $450 \mathrm{~nm}$ ). Figure 3 shows Job plots for the three polymer systems. In all systems, the maximum appeared at $X=0.5$, where $X=\left[\mathrm{Na}^{+} \mathrm{PyS}^{-}\right] /$

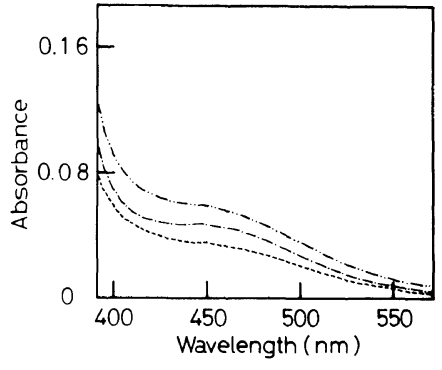

Figure 2. Comparison of the $\mathrm{CT}$ band of $\mathrm{Na}^{+} \mathrm{PyS}^{-}$/ $\mathrm{Na}^{+} 2-\mathrm{AQS}^{-}$in $\mathrm{PVAH}^{+} \mathrm{Cl}^{-}$solution $(-\cdots-)$, in $\mathrm{PAAH}^{+}$ $\mathrm{Cl}^{-}$solution (-.-), and $\mathrm{PDDP}^{+} \mathrm{Cl}^{-}$solution (--.--). $\left[\mathrm{Na}^{+} \mathrm{PyS}^{-}\right]=1.10 \times 10^{-4} \mathrm{M}, \quad\left[\mathrm{Na}^{+} 2-\mathrm{AQS}^{-}\right]=1.10 \times$ $10^{-4} \mathrm{M},[$ Polymer $]=4.40 \times 10^{-4} \mathrm{M}$.

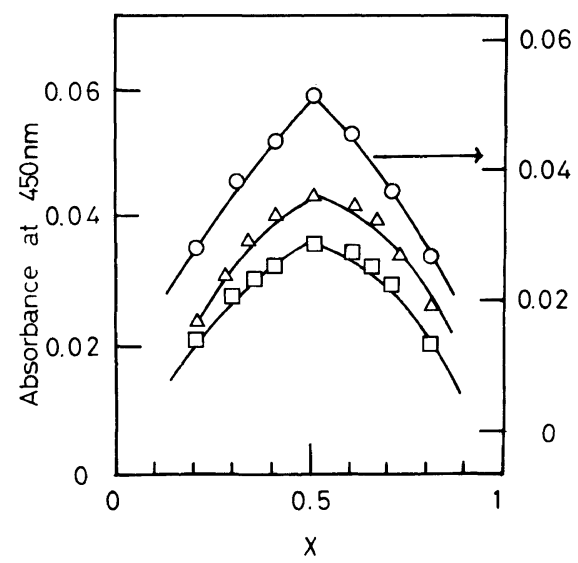

Figure 3. Continuous variation plot for CT complexation between $\mathrm{PyS}^{-}$and 2-AQS ${ }^{-}$in aqueous solution of $4.40 \times 10^{-4} \mathrm{M} \mathrm{PVAH}^{+} \mathrm{Cl}^{-}(-\mathrm{O}-), \mathrm{PAAH}^{+} \mathrm{Cl}^{-}(-\triangle-)$, and $\mathrm{PDDP}^{+} \mathrm{Cl}^{-}(-\square-)$. Cells with a light path of 10 $\mathrm{mm}$ were used. $X=\left[\mathrm{Na}^{+} \mathrm{PyS}^{-}\right] /\left(\left[\mathrm{Na}^{+} \mathrm{PyS}^{-}\right]+\left[\mathrm{Na}^{+} 2-\right.\right.$ $\left.\left.\mathrm{AQS}^{-}\right]\right),\left[\mathrm{Na}^{+} \mathrm{PyS}^{-}\right]+\left[\mathrm{Na}^{+} 2-\mathrm{AQS}^{-}\right]=2.20 \times 10^{-4} \mathrm{M}$.

$\left(\left[\mathrm{Na}^{+} \mathrm{PyS}^{-}\right]+\left[\mathrm{Na}^{+} 2-\mathrm{AQS}^{-}\right]\right)$. Therefore, it can be concluded that the $1: 1$ type CT complex is dominantly formed between $\mathrm{PyS}^{-}$and 2$\mathrm{AQS}^{-}$in the vicinity of the polyions.

In the present systems, $\mathrm{PyS}^{-}$and $2-\mathrm{AQS}^{-}$ are bound to the polyions through the counterion binding, directing their charged groups $\left(-\mathrm{SO}_{3}{ }^{-}\right)$to cationic charged sites on the polyion. And, their aromatic parts can easily overlap at the outside of the polyion surface keeping an enough distance to form the CT complex. 
Since the CT complexation is achieved by the counterion binding to the polyions, it should be influenced by the charge density and species of charged groups on the polyion and its chain flexibility. $\mathrm{PVAH}^{+} \mathrm{Cl}^{-}$and $\mathrm{PAAH}^{+}$ $\mathrm{Cl}^{-}$are typical vinylic polyelectrolytes having a high charge density on their polymer chains (the axial charge spacing on the polyions is $c a$. $2.5 \AA$ ). On the other hand, $\mathrm{PDDP}^{+} \mathrm{Cl}^{-}$is a cationic polyelectrolyte having less charge density than $\mathrm{PVAH}^{+} \mathrm{Cl}^{-}$and $\mathrm{PAAH}^{+} \mathrm{Cl}^{-}$ (the axial charge spacing on the polyion is $c a$. $4.9 \AA) .{ }^{19}$ This means that the charge density of the polyions is in the following order; $\mathrm{PDDP}^{+}<\mathrm{PVAH}^{+}, \mathrm{PAAH}^{+}$. In addition, both $\mathrm{PVAH}^{+} \mathrm{Cl}^{-}$and $\mathrm{PAAH}{ }^{+} \mathrm{Cl}^{-}$have less bulky charged groups, that is, primary ammonium groups $\left(-\mathrm{NH}_{3}{ }^{+}\right)$, whereas $\mathrm{PDDP}^{+} \mathrm{Cl}^{-}$has more bulky charged groups, that is, quaternary ammonium groups with two methyl groups $\left(\left(\mathrm{CH}_{3}\right)_{2} \mathrm{~N}^{+}<\right)$. These facts indicate that both $\mathrm{PVAH}^{+}$and $\mathrm{PAAH}^{+}$can bind the aromatic counterions more strongly than $\mathrm{PDDP}^{+}$and the CT complexation in the vicinity of both $\mathrm{PVAH}^{+}$and $\mathrm{PAAH}^{+}$are more effective than $\mathrm{PDDP}^{+}$. Moreover, $\mathrm{PDDP}^{+}$ has a rigid polymer chain due to its piperidinium ring, on the other hand, both $\mathrm{PVAH}^{+}$ and $\mathrm{PAAH}^{+}$have more flexible main chain because they are vinylic polymer. Consequently, they can take more favorable conformations for the CT complexation than $\mathrm{PDDP}^{+}$. However, in comparison the CT band in the $\mathrm{PVAH}^{+}$system with that in the $\mathrm{PAAH}^{+}$system, the intensity is in the order of $\mathrm{PAAH}^{+}>$ $\mathrm{PVAH}^{+}$. We may elucidate this result as follows. Since $\mathrm{PAAH}^{+}$has more flexible side chain due to the methylene spacer between the main chain and the primary ammonium group, it seems that $\mathrm{PAAH}^{+}$can take suitable conformation for the CT complexation. Consequently, it seems that $\mathrm{PAAH}^{+}$is the most effective polyelectrolyte among the samples used in this study for the CT complexation between $\mathrm{PyS}^{-}$and 2-AQS ${ }^{-}$.

To study more carefully the extent of interaction between the polyion and counterions, we applied an ultrafiltration method for solutions of $\mathrm{Na}^{+} \mathrm{PyS}^{-}$and $\mathrm{Na}^{+} 2-\mathrm{AQS}^{-}$in the presence and the absence of the polyions, under the same concentrations of polymer and counterions. The absorption spectra of filtrates of each polymer system were compared with those of reference solutions which contained only $\mathrm{Na}^{+} \mathrm{PyS}^{-}$or $\mathrm{Na}^{+} 2-\mathrm{AQS}^{-}$. In all the polymer systems containing $\mathrm{Na}^{+} \mathrm{PyS}^{-}$or $\mathrm{Na}^{+} 2-\mathrm{AQS}^{-}$, the absorption spectra of filtrates show the same shape and peak position to that of the reference solution, indicating that the filtrates of all polymer systems contain only the counterions which do not bind to the polyions (free counterion). The band intensity of the filtrates was about $1-5 \%$ of that of the references, suggesting that most of the counterions were bound to the polyion through the counterion binding. In addition, for $\mathrm{Na}^{+} \mathrm{PyS}^{-}$ and $\mathrm{Na}^{+} 2-\mathrm{AQS}^{-}$, intensity decreased in the order, Reference $>\mathrm{PDDP}^{+} \mathrm{Cl}^{-}>\mathrm{PVAH}^{+} \mathrm{Cl}^{-}>$ $\mathrm{PAAH}^{+} \mathrm{Cl}^{-}$(not shown here). This indicates that the number of free counterions in a polymer system is increasing in the above order; the degree of interaction between polyions and counterions follows the order, $\mathrm{PAAH}{ }^{+} \mathrm{Cl}^{-}>$ $\mathrm{PVAH}^{+} \mathrm{Cl}^{-}>\mathrm{PDDP}^{+} \mathrm{Cl}^{-}$. Consequently, $\mathrm{PyS}^{-}$and 2-AQS ${ }^{-}$bind effectively to polyion through the counterion binding in that order, and hence CT complexation between $\mathrm{PyS}^{-}$ and $2-\mathrm{AQS}^{-}$occurs effectively in this order in the vicinity of polyion.

To confirm the above, the solubility of these polyelectrolytes in solution containing both $\mathrm{Na}^{+} \mathrm{PyS}^{-}$and $\mathrm{Na}^{+} 2-\mathrm{AQS}^{-}$was measured. Figure 4 shows the observed solubility diagrams of $\mathrm{PVAH}^{+} \mathrm{Cl}^{-}$(a), $\mathrm{PAAH}^{+} \mathrm{Cl}^{-}$(b), and $\mathrm{PDDP}^{+} \mathrm{Cl}^{-}$(c) in $\mathrm{Na}^{+} \mathrm{PyS}^{-} / \mathrm{Na}^{+} 2-\mathrm{AQS}^{-}$ $(1: 1)$ solutions. The precipitation region (hatched) in the diagrams spreads in the order, $\mathrm{PAAH}^{+} \mathrm{Cl}^{-}>\mathrm{PVAH}^{+} \mathrm{Cl}^{-}>\mathrm{PDDP}^{+} \mathrm{Cl}^{-}$, which is in agreement with the intensity of the CT band (Figure 2) and the results of the ultrafiltration method. Generally, the precipitation behavior of polyelectrolytes by 


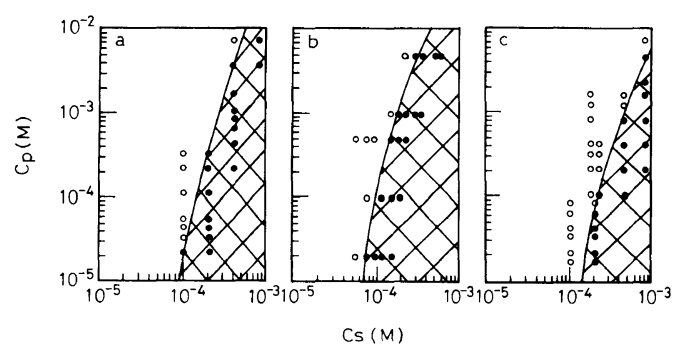

Figure 4. Solubility diagrams of $\mathrm{PVAH}^{+} \mathrm{Cl}^{-}$(a), PAAH ${ }^{+} \mathrm{Cl}^{-}$(b), and $\mathrm{PDDP}^{+} \mathrm{Cl}^{-}$(c) in aqueous $\mathrm{Na}^{+}$ $\mathrm{PyS}^{-} / \mathrm{Na}^{+} 2-\mathrm{AQS}^{-}(1: 1)$ solutions. Solid symbols indicate turbid solution or precipitation of the polymers. $C_{\mathrm{p}}$ and $C_{\mathrm{s}}$ indicate concentration of polymers in residue molar concentration $(M)$ and the molar concentration of aromatic salts $\left(\left[\mathrm{Na}^{+} \mathrm{PyS}^{-}\right]:\left[\mathrm{Na}^{+} 2-\mathrm{AQS}^{-}\right]=1: 1\right)$, respectively.

added salts can be explained in terms of the counterion binding and/or the ion pair formation. ${ }^{20}$ From intensity of the CT bands, ultrafiltration data and solubility measurements, $\mathrm{PAAH}^{+}$attracts aromatic counterions most strongly and is the most favorable polycation for the counterion binding and CT complexation. The present work shows polyelectrolyte having high charge density, less bulky charged groups and more flexible main and side chains on the polyion is effective for the counterion binding and $\mathrm{CT}$ complexation.

\section{REFERENCES}

1. F. Oosawa, "Polyelectrolytes," Marcel Dekker Inc., New York, N.Y., 1971.

2. H. Eisenberg and R. G. Mohan, J. Chem. Phys., 63,
671 (1959).

3. C. J. Leyte, H. L. Zuiderweg, and J. H. Vledder, Spectrochim. Acta, 23A, 1397 (1967).

4. I. Satake, M. Fukuda, T. Ohta, K. Nakamura, F. Fujita, A. Yamaguchi, and H. Kimizuka, J. Polym. Sci., Polym. Phys. En., 10, 2343 (1972).

5. S. Miyamoto, Macromolecules, 14, 1054 (1981).

6. J. Mattal and C. T. J. Kwak, J. Phys. Chem., 86, 1026 (1982).

7. A. E. Lewis, J. T. Barkley, R. R. Reams, D. L. Hansen, and T. St Pierre, Macromolecules, 17, 2874 (1984).

8. T. Kitano, S. Kawaguchi, K. Ito, and A. Minakata, Macromolecules, 20, 1598 (1987).

9. T. Itaya, K. Ueda, H. Ochiai, and A. Imamura, Polym. J., 25, 545 (1993).

10. T. Itaya, H. Ochiai, T. Aoyama, K. Ueda, and A. Imamura, J. Polym. Sci., B, Polym. Phys., 32, 171 (1994).

11. T. Itaya, K. Ueda, H. Ochiai, and A. Imamura, Macromolecules, 26, 6021 (1993).

12. T. Itaya, Y. Kawabata, H. Ochiai, K. Ueda, and A. Imamura, Bull. Chem. Soc. Jpn., 67, 1538 (1994).

13. T. Itaya, Y. Kawabata, H. Ochiai, K. Ueda, and A. Imamura, Bull. Chem. Soc. Jpn., 67, 2047 (1994).

14. Y. Kawabata, T. Itaya, Y. Sasaki, H. Ochiai, K. Ueda, and A. Imamura, submitted for publication.

15. M. Hara, H. A. Lee, and J. Wu, J. Polym. Sci. Phys. Ed., 25, 1407 (1987).

16. H. Ochiai, Y. Anabuku, O. Kojima, K. Tominaga, and I. Murakami, J. Polym. Sci., Polym. Phys. Ed., 28, 233 (1990).

17. H. Ochiai, M. Handa, H. Matsumoto, T. Moriga, and I. Murakami, Makromol. Chem., 186, 2547 (1985).

18. D. Job, Ann. Chem. Phys., 10(9), 113 (1928).

19. H. E. Rios, C. Gamboa, G. Ternero. J. Polym. Sci., Polym. Phys. Ed., 29, 805 (1991).

20. A. Ikegami and N. Imai, J. Polym. Sci., 56, 133 (1962). 